\title{
NUCLEAR DNA CONTENT AND PLOIDY LEVEL IN APOMICTIC BUFFELGRASS GENOTYPES
}

\section{CONTENIDO DE ADN NUCLEAR Y NIVEL DE PLOIDÍA EN GENOTIPOS APOMÍCTICOS DE BUFFELGRASS}

\author{
Edgardo J. Carloni-Jarrys ${ }^{1 *}$, Ma. Cristina Acosta-Bragato ${ }^{2,3}$ y Karina Grunberg-Fraga ${ }^{1,3}$
}

\begin{abstract}
'Instituto de Fisiología y Recursos Genéticos Vegetales, Centro de Investigaciones Agropecuarias, Instituto Nacional de Tecnología Agropecuaria Av. 11 de Septiembre 4755. X5020ICA, Córdoba, Argentina. TE. 0351 4973636. ${ }^{2}$ Instituto Multidisciplinario de Biología Vegetal, CONICET, Facultad de Ciencias Exactas, Físicas y Naturales, Universidad Nacional de Córdoba. Casilla de Correo 495. 5000, Córdoba, Argentina. TE: 0351-4331056 Int 29. ${ }^{3}$ Consejo de Nacional Investigaciones Científicas y Técnicas, Godoy Cruz 2290, C1425FQB, CABA, Argentina.
\end{abstract}

*Autor para correspondencia (carloni.edgardo@inta.gob.ar; edgardocarloni@gmail.com)

\section{SUMMARY}

Buffelgrass [Pennisetum ciliare (L.) Link syn. Cenchrus ciliaris L.] is a polyploid fodder grass that reproduces mostly via apomixis. The wide genomic and cytological diversity present in the species indicates that the active field collection at Instituto de Fisiología y Recursos Genéticos Vegetales (IFRGV) of the National Institute of Agricultural Technology (INTA) might contain individuals with different ploidy levels. This researche aimed to determine nuclear DNA content and ploidy level of introduced apomictic germplasm of buffelgrass. Cytological studies showed different ploidy levels in the germplasm. Genetic resources include tetraploid $(2 n=4 x=36)$ and aneuploid $(2 n=43$ and 44$)$ individuals. The 10 materials that exhibited $2 \mathrm{C}$ values ranging between 3.04 and $3.17 \mathrm{pg}$ were tetraploid cytotypes. The values of the four aneuploid individuals with 43 chromosomes ranged between 3.83 and $3.86 \mathrm{pg}$, whereas aneuploid individual with 44 chromosomes had a $2 \mathrm{C}$ value of $3.94 \mathrm{pg}$. Number of chromosomes and nuclear DNA content were correlated. In addition, a model equation was obtained to estimate DNA ploidy value in buffelgrass genotypes.

Index words: Cenchrus ciliaris, germplasm bank, flow cytometry, fodder species, polyploid.

\section{RESUMEN}

Buffelgrass [Pennisetum ciliare (L.) Link syn. Cenchrus ciliaris L.] es una gramínea forrajera, poliploide, donde la mayoría de sus miembros se reproducen por apomixis. La amplia diversidad genómica y citológica existente en la especie hace prever que individuos con diferentes niveles de ploidía podrían ser parte de la colección activa mantenida en campo que se encuentra en el Instituto de Fisiología y Recursos Genéticos Vegetales (IFRGV) del Instituto Nacional de Tecnología Agropecuaria (INTA). Los objetivos del presente trabajo fueron determinar el contenido de ADN nuclear y el nivel de ploidía en un germoplasma apomíctico introducido de buffelgrass. Los estudios citológicos demostraron que el germoplasma presenta diferentes niveles de ploidía. La constitución genética está representada por individuos tetraploides $(2 n=4 x=36)$ y aneuploides $(2 n=43$ y 44$)$. Los 10 materiales que presentaron valores $2 \mathrm{C}$ comprendidos en un rango entre 3.04 y $3.17 \mathrm{pg}$ fueron citotipos tetraploides. Los cuatro materiales aneuploides con 43 cromosomas tuvieron valores que oscilan entre 3.83 y $3.86 \mathrm{pg}$, mientras que el individuo aneuploide con 44 cromosomas tiene valor $2 \mathrm{C}$ de $3.94 \mathrm{pg}$. Se encontró una correlación entre el número de cromosomas y el contenido de ADN nuclear. Conjuntamente se obtuvo una ecuación modelo que podría utilizarse para estimar el valor de ploidía en genotipos de buffelgrass.
Palabras clave: Cenchrus ciliaris, banco de germoplasma, citometría de flujo, especies forrajeras, poliploides.

\section{INTRODUCTION}

Buffelgrass [Pennisetum ciliare (L.) Link syn. Cenchrus ciliaris L.] is a forage grass species naturally distributed in subtropical and semiarid areas in Africa and India (Goel et al., 2011). The species has been incorporated into genetic breeding programs in several subtropical regions worldwide, due to its drought tolerance and forage aptitude. Buffelgrass reproduces mainly via apomixis (Ozias-Akins and van Dijk, 2007); hence, many cultivars are derived from the selection of natural ecotypes from their site of origin (Hanselka et al., 2004). However, the detection of a source of sexuality (Quiroga et al., 2013) and the use of biotechnological tools (Carloni et al., 2014; López et al., 2013) have enabled novel strategies in breeding programs.

In Argentina, there is an active field collection of buffelgrass held by the Instituto de Fisiología y Recursos Genéticos Vegetales (IFRGV), Centro de Investigaciones Agropecuarias (CIAP) and Instituto Nacional de Tecnología Agropecuaria (INTA). These genetic resources of buffelgrass have been the basis for the development of new materials with higher tolerance to water and salt stress, and with higher dry matter productivity (Griffa et al., 2010; López et al., 2013).

Buffelgrass belongs to a polyploid agamic complex, with the base chromosome number $x=9$, and with representative tetraploid $(2 n=4 x=36)$, pentaploid $(2 n=5 x$ $=45)$, hexaploid $(2 n=6 x=54)$ and septaploid $(2 n=7 x=$ 63) cytotypes (Burson et al., 2015; Hignight et al., 1991; Kharrat-Souissi et al., 2013; Visser et al., 1998). While most individuals are characterized as euploid, there are also aneuploids with different number of chromosomes $(2 n=32$, $40,43,48$ ) that do not coincide with an exact multiple of the 
basic number (Burson et al., 2012). The wide genomic and cytological diversity present in the species suggests that individuals with different ploidy levels might be part of the buffelgrass collection.

Several studies have demonstrated the usefulness of flow cytometry (FCM) in taxonomic studies. This technique is used to quantify the nuclear DNA content of a plant ( $2 \mathrm{C}$ value) and to infer the ploidy level using that value (Doležel et al., 2007). The interpretation of results in terms of ploidy is based on the study of nuclear DNA content (2C value) obtained from the analysis of both an unknown sample and a reference standard (Galbraith et al., 2001; Loureiro et al., 2006).

Six different ploidy groups have been identified using FCM in buffelgrass, with four of them corresponding to euploid and two to aneuploid cytotypes (Burson et al., 2012; Kharrat-Souissi et al., 2013). For aneuploids, Burson et al. (2012) established a range from 3.43 to 3.78 pg of nuclear DNA for individuals with 37 and 44 chromosomes, respectively. However, the analyses conducted by Kharrat-Souissi et al. (2013) showed that pentaploid individuals $(2 n=5 x=$ 45 ) exhibited similar $2 \mathrm{C}$ values (3.63 to $3.74 \mathrm{pg}$ ). Therefore, the present study aimed to determine and compare the nuclear DNA content and ploidy level of apomictic genotypes of buffelgrass.

\section{MATERIALS AND METHODS}

\section{Plant material}

Table 1 lists the apomictic buffelgrass genotypes used in this study. All materials are part of an active buffelgrass collection held at Instituto de Fisiología y Recursos Genéticos Vegetales (IFRGV) of the Instituto Nacional de Tecnología Agropecuaria (INTA), Córdoba, Argentina (600 masl, $31^{\circ} 24^{\prime}$ South latitude, $61^{\circ} 11^{\prime}$ West longitude). Seeds were collected from plots established at the IFRGV-INTA field in January-March 2014 and stored in paper bags at 6 ${ }^{\circ} \mathrm{C}$ (to avoid loss of viability) until the time of the analyses.

\section{Flow cytometry analysis (FCM)}

FCM analyses were performed using fresh tissue of leaves from the active collection of buffelgrass. Samples were processed following the protocol of Doležel et al. (2007), with small modifications. Buffelgrass leaf segments of 4 to $6 \mathrm{~cm}^{2}$ and of the reference standard [Zea mays CE-777 (2C = 5.43 pg DNA)] (Lysák and Doležel, 1998) were chopped together in $1 \mathrm{~mL}$ Otto I buffer $(0.1 \mathrm{M}$ citric acid monohydrate, $0.5 \%$ Tween 20). Samples were filtered through a $30 \mu \mathrm{m}$ mesh sieve and centrifuged at $1500 \mathrm{rpm}$ for 5 min; all but $100 \mu \mathrm{L}$ of the supernatant was removed, and the remainder left in a $1.5 \mathrm{~mL}$ tube. Samples were resuspended in $100 \mu \mathrm{L}$ Otto I buffer with mild agitation and incubated into a cold chamber $\left(4^{\circ} \mathrm{C}\right)$ for $24 \mathrm{~h}$. Then, $1 \mathrm{~mL}$ Otto II buffer $\left(0.4 \mathrm{M} \mathrm{Na}_{2} \mathrm{HPO}_{4} .12 \mathrm{H}_{2} \mathrm{O}\right), 50 \mu \mathrm{g} \mathrm{mL}^{-1}$ of propidium iodide (PI) (Sigma-Aldrich ${ }^{\circledR}$, St. Louis, MO, USA), and $50 \mathrm{mg} \mathrm{mL}^{-1}$ of RNase (Sigma-Aldrich ${ }^{\circledR}$, St. Louis, MO, USA) were added. Samples were incubated for $10 \mathrm{~min}$ at room temperature and run in a BD FACSCantoTM II FCM cytometer (BD Biosciences, San Jose, California, USA).

For each genotype, a minimum of six repetitions, obtained on $3 \mathrm{~d}$ (two repetitions per individual per day) were performed, as recommended by Doležel et al. (2007) to avoid potential differences between the analyses performed on different days (Loureiro et al., 2006). Relative nuclear DNA content of plants was expressed using a DNA fluorescence index (DI), considering the reference standard $\left(\mathrm{DI}=2 \mathrm{C}_{\text {buffelgrass }} / 2 \mathrm{C}_{\text {z. mays }}\right)$.

Genome size was estimated for each individual in pg (2C value) using the following formula:

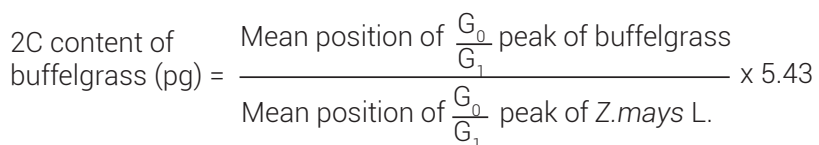

Where 5.43 is the nuclear DNA content in pg of Zea mays CE-777 (Lysák and Doležel, 1998).

\section{Cytogenetic Analysis}

Mitotic chromosome count was performed in squashed cells of the meristematic tissue of the root, using an adapted version of the protocol of Negritto et al. (2008). Roots were collected from germinated seeds in Petri dishes in the growth chamber. Culture conditions were 27 and $25^{\circ} \mathrm{C}$ with a photoperiod of $16 \mathrm{~h}$ light and $8 \mathrm{~h}$ dark, respectively. Lights in the growth chamber were turned on at 06:00 p.m. Under these growth conditions, mitotic cells could be obtained by collecting roots between 10:30 and 11:00 p.m.

Polymerization of microtubules of the mitotic spindle was prevented by treating roots with 8-hydroxyquinoline $(2 \mathrm{mM})$ for $3 \mathrm{~h}$ at room temperature and $3 \mathrm{~h}$ at $4{ }^{\circ} \mathrm{C}$. After this period, the microtubule inhibitor was removed, and the plant material was immersed in fixative [1:3 glacial acetic acid:absolute ethyl alcohol ( $\mathrm{v} / \mathrm{v})]$ for at least $48 \mathrm{~h}$. Before squashing, roots were treated with a $2 \%$ pectinase-cellulase solution. Root tips were removed with histological needles under a stereoscopic microscope and placed on a slide. Squashing was performed with a drop of $60 \%$ acetic acid, and the coverslip was removed after freezing the material with liquid air. Slides were dried using a heater for 
72 h. Finally, plant material was stained with $2 \%$ GIEMSA solution and mounted with Entellan. Chromosomes were observed under an optical microscope and photographed using $60 \times 1.5$ lenses under an inverted microscope (Nikon $B$, Eclipse Ti-E).

\section{Statistical Analysis}

The relationship between chromosome number and nuclear DNA content was explored via simple linear regression analysis: the dependent variable was chromosome number of each individual and the regression variable was nuclear DNA content (pg). The analysis was performed using InfoStat statistical software (Di Rienzo et al., 2012).

\section{RESULTS}

Flow cytometry analysis

Histograms of relative fluorescence intensity of the three buffelgrass materials analyzed along with Z. mays L. as reference standard are shown in Figure 1. The analysis of vegetal samples showed four peaks, two of them corresponding to nuclear DNA content of buffelgrass and the other two corresponding to maize. The dominant peaks correspond to the nuclei at the $G_{0} / G_{1}$ phase (nuclear DNA content, 2C), whereas the minor peaks correspond to nuclei at the $\mathrm{G}_{2}$ phase of the cell cycle (nuclear DNA content, 4C). The absence of peak overlap indicated that the internal standard was adequate.

In general, the coefficient of variation (CV) of the peaks generated in the $G_{0} / G_{1}$ phase was below $3 \%$. In maize,
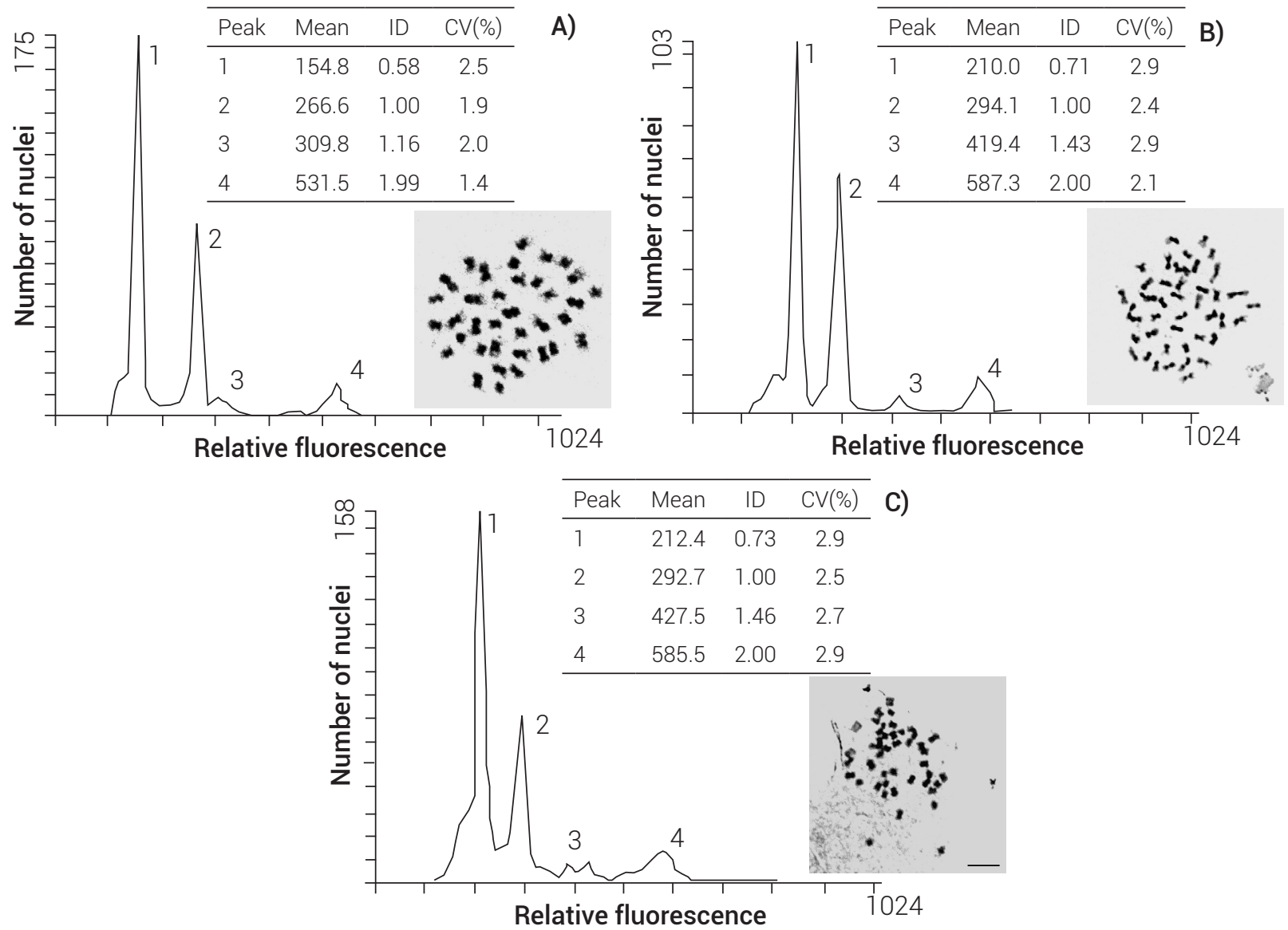

Figure 1. Histograms of relative fluorescence intensity obtained from the simultaneous analysis of isolated nuclei of leaves of buffelgrass and the reference standard Zea mays CE-777 $(2 \mathrm{C}=5.43 \mathrm{pg}$ DNA). Peaks 1 and 2 correspond to the nuclei in $G_{0} / G_{1}$ phase of buffelgrass ( 1 ) and Zea mays (2). Peaks 3 and 4 correspond to the nuclei in phase $G_{2}$ of buffelgrass (3) and of Zea mays (4). Micrographs of somatic chromosomes of apomictic buffelgrass genotypes with $2 n=4 x=36$ [(A) RN 49], $2 n=43$ [(B) RN 136] and 2n = 44 [(C) RN 145] chromosomes. Bar. Scale correspond to $5 \mu \mathrm{m}$ for all figures. 
mean CV was $2.25 \pm 0.41(n=119)$, and the CVs had values between 0.97 and $2.98 \%$. In buffelgrass, considering all the measurements of the different genotypes $(n=119)$, the mean of $\mathrm{CV}$ values was $2.69 \pm 0.56$. Out of all measurements, $76 \%$ had CVs values $\leq 3 \%$ and $24 \%$ showed $\mathrm{CV}$ s between 3 and $4 \%$. The analysis of the mean of each genotype separately showed that only two genotypes had CVs of $3.04 \%$ (RN 153) and $3.13 \%$ (RN 62) (Table 1).

Mean DI value $\left(2 \mathrm{C}_{\text {buffelorass }} / 2 \mathrm{C}_{\text {z. mays }}\right)$ was variable, with values ranging between 0.559 (RN 148) and 0.726 (RN 145). Nuclear DNA content (2C value) of each genotype was calculated with these indices (Table 1).

\section{Cytogenetic analysis}

All the genotypes were polyploids, with 10 of them being tetraploids $(2 n=4 x=36)$ and five aneuploids $(2 n=43$ and $2 n=44$ chromosomes). These results confirm that the different $2 \mathrm{C}$ values determined by FCM correspond to individuals of different ploidy levels (Figure 2). The 10 genotypes with $2 \mathrm{C}$ values within a range between 3.04 and $3.17 \mathrm{pg}$ were considered as tetraploid cytotypes. The four aneuploid genotypes with 43 chromosomes had values ranging between 3.83 and $3.86 \mathrm{pg}$, whereas aneuploids with 44 chromosomes had $2 \mathrm{C}$ value of $3.94 \mathrm{pg}$.

The scatter plot shows a positive relationship between the number of chromosomes observed in each individual and estimations of nuclear DNA content (Figure 3). In addition, the linear regression analysis showed a linear relationship between the number of chromosomes (dependent variable) and nuclear DNA content (regression variable) $(\mathrm{P}$ $<0.0001$ ) with an $R^{2}=0.9841$. Accordingly, the following equation of the model is proposed: $y=7.2464+9.2856 x$.

\section{DISCUSSION}

The results of this work indicate that the apomictic genotypes present in the active buffelgrass collection possess different ploidy levels. The genetic resources of the IFRGV collection are represented by tetraploids $(2 n=4 x$ $=36)$ and aneuploids $(2 n=43$ and $2 n=44)$; these cytotypes were already mentioned for this species (Burson et al., 2012; Hignight et al., 1991; Kharrat-Souissi et al., 2013). The most frequent cytotypes are those with $2 n=4 x=36$, and the number of chromosomes coincides with the most commonly observed in buffelgrass (Hignight et al., 1991).

Cytological and molecular studies showed that cytotypes with 36 chromosomes are segmental allotetraploids, showing at the average of two to four quadrivalents and 10 to 14 bivalents during diakinesis and metaphase I (Hignight et al., 1991; Jessup et al., 2003; Visser et al., 1998). Aneuploid cytotypes with 43 and 44 chromosomes might have originated from a combination of events, such

Table 1. DNA fluorescence index (DI), nuclear DNA content (2C value), coefficients of variation (CV) determined by flow cytometry and chromosome number (CN) in 15 apomictic buffelgrass genotypes.

\begin{tabular}{|c|c|c|c|c|c|}
\hline Genotype & $\mathrm{n}$ & $\mathrm{DI} \pm$ S.D. & $2 \mathrm{C}(\mathrm{pg}) \pm$ S.D. $^{\dagger}$ & CV $(\%) \pm$ S.D. ${ }^{+\dagger}$ & $\mathrm{CN}$ \\
\hline RN 148 & 6 & $0.559 \pm 0.006$ & $3.04 \pm 0.03$ & $2.51 \pm 0.58$ & 36 \\
\hline RN 64 & 8 & $0.564 \pm 0.005$ & $3.06 \pm 0.03$ & $2.71 \pm 0.12$ & 36 \\
\hline RN 157 & 8 & $0.564 \pm 0.005$ & $3.06 \pm 0.03$ & $2.97 \pm 0.25$ & 36 \\
\hline RN 153 & 8 & $0.564 \pm 0.006$ & $3.07 \pm 0.03$ & $3.04 \pm 0.37$ & 36 \\
\hline RN 66 & 8 & $0.567 \pm 0.004$ & $3.08 \pm 0.02$ & $2.85 \pm 0.22$ & 36 \\
\hline RN 63 & 7 & $0.571 \pm 0.006$ & $3.10 \pm 0.03$ & $2.88 \pm 0.31$ & 36 \\
\hline RN 52 & 8 & $0.572 \pm 0.011$ & $3.10 \pm 0.06$ & $2.84 \pm 0.65$ & 36 \\
\hline RN 62 & 8 & $0.580 \pm 0.004$ & $3.15 \pm 0.02$ & $3.13 \pm 0.42$ & 36 \\
\hline RN 67 & 8 & $0.583 \pm 0.006$ & $3.16 \pm 0.03$ & $2.94 \pm 0.32$ & 36 \\
\hline RN 49 & 8 & $0.584 \pm 0.005$ & $3.17 \pm 0.02$ & $2.91 \pm 0.35$ & 36 \\
\hline RN 50 & 8 & $0.705 \pm 0.004$ & $3.83 \pm 0.02$ & $2.66 \pm 0.39$ & 43 \\
\hline RN 136 & 6 & $0.707 \pm 0.004$ & $3.84 \pm 0.02$ & $2.74 \pm 0.34$ & 43 \\
\hline RN 147 & 11 & $0.708 \pm 0.007$ & $3.84 \pm 0.04$ & $2.32 \pm 0.46$ & 43 \\
\hline RN 51 & 11 & $0.711 \pm 0.004$ & $3.86 \pm 0.02$ & $1.72 \pm 0.77$ & 43 \\
\hline RN 145 & 6 & $0.726 \pm 0.003$ & $3.94 \pm 0.02$ & $2.64 \pm 0.38$ & 44 \\
\hline
\end{tabular}

†: $2 \mathrm{C}$ value is the average of the number of times that the sample (n) was analyzed, expressed in picograms (pg). The values were obtained by analyzing the nuclei isolated from buffelgrass and Zea mays CE-777 ( $2 \mathrm{C}=5.43 \mathrm{pg}$ DNA) as reference standard; ${ }^{++}$: Mean of coefficient of variation and standard deviation (CV \pm S.D.) of fluorescence intensity of nuclei in the $G_{0} / G_{1}$ phase of buffelgrass. S.D.: Standard deviation; RN: Number of registration assigned by IFRGV. 


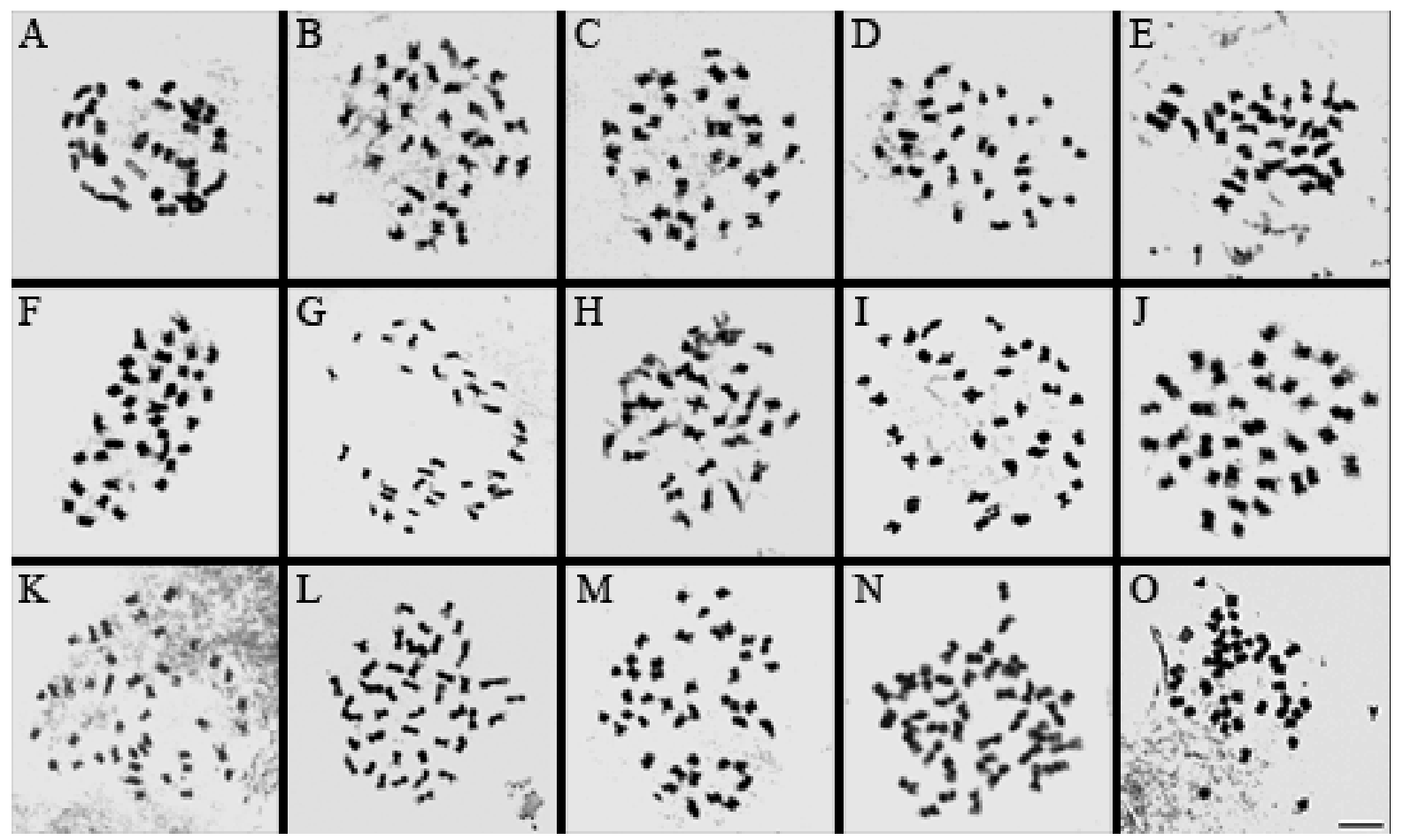

Figure 2. Micrographs of somatic chromosomes of apomictic buffelgrass genotypes with $2 \mathrm{n}$ : 36 [(A) RN 148, (B) RN 64, (C) RN 157, (D) RN 153, (E) RN 66, (F) RN 63, (G) RN 52, (H) RN 62, (I) RN 67 and (J) RN 49], 2n: 43 [(K) RN 50, (L) RN 136, (M) RN 147 and (N) RN 51] and 2n: 44 [(O) RN 145] chromosomes. Bar. Scale corresponds to $5 \mu \mathrm{m}$ for all figures.

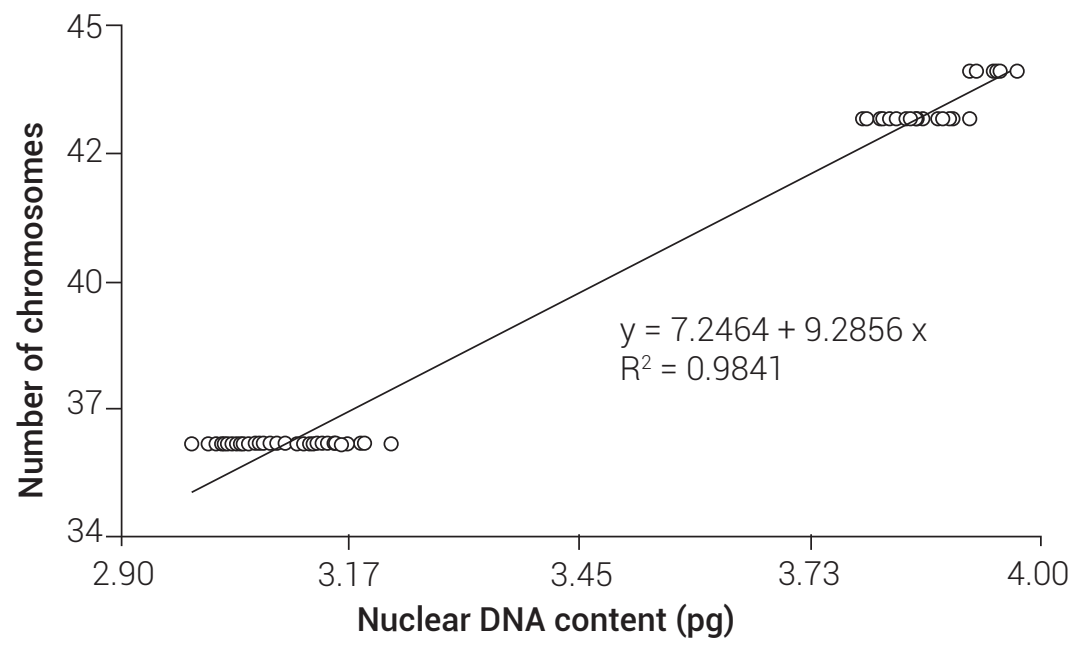

Figure 3. Linear regression analysis between the number of chromosomes and nuclear DNA content in each buffelgrass genotype. 
as fertilization of a sexual genotype with unbalanced pollen or from hybridization of an unreduced gamete (hybrids $B_{\| \prime \prime}$ $2 n+n)$ (Bashaw and Hignight, 1990; Burson et al., 2012; Hignight et al., 1991). These events, whichever their origin, might increase the ploidy level of the species in their habitat, which is maintained through the apomictic mode of reproduction observed in buffelgrass (Burson et al., 2002; Hignight et al., 1991).

The range of nuclear DNA content in tetraploids (3.04 to $3.18 \mathrm{pg}$ ) is consistent with previously mentioned values (Burson et al., 2012; Kharrat-Souissi et al., 2013). However, the $2 \mathrm{C}$ values obtained in individuals with $2 \mathrm{n}=43$ and 44 chromosomes differ from those of their aneuploid relatives from other international collections. Accordingly, Burson et al. (2012) observed that materials with 37 to 44 chromosomes are within the $2 \mathrm{C}$ value range of 3.43 to $3.78 \mathrm{pg}$. In this study, $2 \mathrm{C}$ values were higher, ranging between 3.83 and $3.94 \mathrm{pg}$ in individuals with 43 and 44 chromosomes, respectively.

The small differences in the values obtained by using FCM compared with those reported by Burson et al. (2012) may be due to methodological differences between laboratories (Doležel et al., 1998). Hence nuclear DNA content determination requires an internal standardization with the standard material of known genome. It is generally recommended that the peak generated by the standard be as close as possible to the peak of the unknown individual. If this is not possible, in order to avoid potential linearity errors (Doležel et al., 2007), the size of the selected standard should not differ more than twice with respect to the study sample.

Burson et al. (2012) used common buffelgrass (T-4464) as internal standard and quantified nuclear DNA content using Pl; they determined a nuclear DNA content in common buffelgrass of $3.08 \mathrm{pg}$ (Burson et al., 2002). In contrast, we used maize (Zea mays CE-777) as internal standard (Lysák and Doležel, 1998). The nuclear DNA content of maize is $5.43 \mathrm{pg}$, a size that complies with the suggested requirement to avoid linearity problems.

Another parameter used here, which differs from those ones used in other laboratories, is the fluorochrome employed to estimate nuclear DNA content. Burson et al. (2012) used DAPI (4', 6-diamidino-2-phenylindole) and incorporated a correction factor to the values obtained from the combined analysis of the internal standard (common buffelgrass) with Sorghum bicolor (L.) Moench line ATx623, both stained with PI. In this study we directly used PI to stain nucleic acid. The difference between fluorochromes is that DAPI preferentially binds to adenine-thymine-rich DNA regions, whereas $\mathrm{PI}$ is an intercalating agent in double stranded DNA, recommended for measuring nuclear DNA (Doležel et al., 1998).

The nuclear isolation buffer is another parameter that might cause divergences between laboratories (Loureiro et al., 2006). Burson et al. (2012) used a commercial staining solution supplied by Partec (Münster, Germany), whereas we used Otto buffer nucleus release. Loureiro et al. (2006) used four different buffers and seven plant species and concluded that there is no universal buffer for that purpose. Likewise, the quality parameters obtained with Otto buffer used as universal buffer were outstanding (Loureiro et al., 2006). Accordingly, the nuclei had good fluorescence intensity and consequently, the CVs were low.

In fluorescence histograms, CV is a measure of nuclear integrity and variation in staining of nuclear DNA. This parameter is used to evaluate the quality of the method and should be presented in all publications (Loureiro et al., 2007). In general, histograms with CV below $3 \%$ are considered acceptable, however in some woody species, CVs $\leq 5 \%$ are accepted (Galbraith et al., 2001). In most of the analyses conducted in this study (76\%), the materials exhibited CV values of $3 \%$ or lower. Only a small proportion (24\%) exceeded those values, but were never above 3.8 $\%$. Moreover, to avoid possible differences observed in the CVs obtained on different squashing dates (Loureiro et al., 2006), a minimum of six independent measurements were taken (two runs a day), as recommended (Doležel et al., 2007). With this strategy, the mean of CV did not exceed 3 $\%$ in any of the aneuploid materials.

As discussed above, here we used several recommended methods aimed at obtaining accurate estimations in nuclear DNA content. Accordingly, we consider that the method applied at the IFRGV-INTA laboratory was appropriate. Moreover, we consider that if differences are due to any methodological variable (reference standard, buffer, fluorochrome or $\mathrm{CV}$ ), it is difficult to identify one of them as an underlying single factor.

\section{CONCLUSIONS}

Our results provide important reference data on nuclear DNA content in buffelgrass and generate a baseline for future studies involving FCM. The model equation generated in this study might be used for predictive purposes in new buffelgrass materials. In addition, while the simplicity of the FCM technique makes it an attractive option, it is important to perform a parallel cytological study for a complete evaluation of results. Accordingly, if $2 \mathrm{C}$ values obtained in our collection had been compared only with those provided by other laboratories, interpretation of results might have been inaccurate. 


\section{ACKNOWLEDGMENTS}

We thank P. Crespo and P. Abadie for assistance with the FCM analysis. This work was supported financially by The Instituto Nacional de Tecnología Agropecuaria (INTA), Argentina, Project REDGEN-1137021 and CONICET PIP 1122011010031.

\section{BIBLIOGRAPHY}

Bashaw E. C. and K. W. Hignight (1990) Gene transfer in apomictic buffelgrass through fertilization of an unreduced egg. Crop Science 30:571-575, doi: 10.2135/cropsci1990.0011183X0030000300 $21 \mathrm{x}$.

Burson B. L., M. A. Hussey, J. M. Actkinson and G. S. Shafer (2002) Effect of pollination time on the frequency of $2 n+n$ fertilization in apomictic buffelgrass. Crop Science 42:1075-1080, https://dx.doi. org/10.2135/cropsci2002.1075.

Burson B. L., J. M. Actkinson, M. A. Hussey and R. W. Jessup (2012) Ploidy determination of buffel grass accessions in the USDA National Plant Germplasm System collection by flow cytometry. South African Journal of Botany 79:91-95, https://dx.doi. org/10.1016/j.sajb.2011.12.003.

Burson B. L., K. Renganayaki, C. D. Dowling, L. L. Hinze and R. W. Jessup (2015) Genetic diversity among pentaploid buffelgrass accessions. Crop Science 55:1637-1645, doi:10.2135/cropsci2014.09.0655

Carloni E., A. Ribotta, E. López C., S. Griffa, M. Quiroga, E. Tommasino and K. Grunberg (2014) Somatic embryogenesis from in vitro anther culture of apomictic buffel grass genotypes and analysis of regenerated plants using flow cytometry. Plant Cell, Tissue and Organ Culture 117:311-322, https://doi.org/10.1007/s11240014-0441-4.

Di Rienzo J. A., F. Casanoves, M. G. Balzarini, L. Gonzalez, M. Tablada y C. W. Robledo (2012) InfoStat. Grupo InfoStat. FCA. Universidad Nacional de Córdoba, Argentina. http://www.infostat.com.ar.

Doležel J., J. Greilhuber, S. Lucretti, A. Meister, M. A. Lysák, L. Nardi and R. Obermayer (1998) Plant genome size estimation by flow cytometry: inter-laboratory comparison. Annals of Botany 82:17-26, https://doi.org/10.1093/oxfordjournals.aob.a010312.

Doležel J., J. Greilhuber and J. Suda (2007) Estimation of nuclear DNA content in plants using flow cytometry. Nature Protocols 2:2233-2244, doi:10.1038/nprot.2007.310

Galbraith D. W., G. M. Lambert, J. Macas and J. Dolezel (2001) Analysis of nuclear DNA content and ploidy in higher plants. Current Protocols in Cytometry 2:7.6:7.6.1-7.6.22. http://doi. org/10.1002/0471142956.cy0706s02.

Goel S., H. D. Singh and S. N. Raina (2011) Cenchrus. In: Wild Crop Relatives: Genomic and Breeding Resources. Millets and Grasses. C. kole (ed.). Springer. Berlin Heidelberg. pp: 31-52, https://doi. org/10.1007/978-3-642-14255-0_3

Griffa S., A. Ribotta, E. López C., E. Tommasino, E. Carloni, C. Luna and K. Grunberg (2010) Evaluation seedling biomass and its components as selection criteria for improving salt tolerance in Buffel grass genotypes. Grass and Forage Science 65:358-361, https://doi org/10.1111/j.1365-2494.2010.00754.x.

Hanselka C. W., M. A. Hussey and F. Ibarra (2004) Buffelgrass. In: Warmseason $\left(C_{A}\right)$ grasses. L. E. Moser, B. L. Burson and L. E. Sollenberger (eds.). American Society of Agronomy, Madison. pp: 477-502.

Hignight K. W., E. C. Bashaw and M. A. Hussey (1991) Cytological and morphological diversity of native apomictic buffelgrass, Pennisetum ciliare (L.) Link. Botanical Gazette 152:214-218, https:// doi.org/10.1086/337882

Jessup R. W., B. L. Burson, G. Burow, Y. M. Wang, C. Chang, Z. Li, A. H. Paterson and M. A. Hussey (2003) Segmental allotetraploidy and allelic interactions in buffelgrass (Pennisetum ciliare (L.) Link syn. Cenchrus ciliaris L.) as revealed by genome mapping. Genome 46:304-313, https://doi.org/10.1139/g03-005.

Kharrat-Souissi A., S. Siljak-Yakovlev, S. C. Brown and M. Chaieb (2013) Cytogeography of Cenchrus ciliaris (Poaceae) in Tunisia. Folia Geobotanica 48:95-113, https://doi.org/10.1007/s12224-012 9137-x

López C. E., E., Tommasino, C. Luna, S. Griffa, E. Carloni, A. Ribotta, M. Quiroga and K. Grunberg (2013) Differential salt-stress response during germination and vegetative growth in in vitro selected somaclonal mutants of Cenchrus ciliaris L. South African Journal of Botany 87:157-163, https://doi.org/10.1016/j.sajb.2013.03.008

Loureiro J., E. Rodriguez, J. Doležel and C. Santos (2006) Comparison of four nuclear isolation buffers for plant DNA flow cytometry. Annals of Botany 98:679-689, https://doi.org/10.1093/aob/ mcl141

Loureiro J., J. Suda, J. Doležel and C. Santos (2007) Flower: a plant dna flow cytometry database. In: Flow Cytometry with Plant Cells. J. Dolezel, J. Greilhuber and J. Suda (eds.). Wiley-VCH Verlag GmbH \& Co. KGaA. Weinheim, Germany. pp:423-454, https:// doi.org/10.1002/9783527610921.ch18.

Lysák M. A. and J. Doležel (1998) Estimation of nuclear DNA content in Sesleria (Poaceae). Caryologia 51:123-132, http://dx.doi.org/10 .1080/00087114.1998.10589127.

Negritto M. A., A. A. Romanutti, M. C. Acosta, E. A. Moscone, A. E. Cocucci and and A. M. Anton (2008) Morphology, reproduction and karyology in the rare Andean Poa gymnantha. Taxon 57:171-178.

Ozias-Akins P. and P. J. van Dijk (2007) Mendelian genetics of apomixis in plants. Annual Review of Genetics 41:509-537, https://doi org/10.1146/annurev.genet.40.110405.090511.

Quiroga M., K. Grunberg, A. Ribotta, E. López C., E. Carloni, E. Tommasino, C. Luna and S. Griffa (2013) Obtaining sexual genotypes for breed ing in buffel grass. South African Journal of Botany 88:118-123, https://doi.org/10.1016/j.sajb.2013.04.016.

Visser N. C., J. J. Spies and H. J. T. Venter (1998) Meiotic chromosome behaviour in Cenchrus ciliaris (Poaceae: Panicoideae). Bothalia 28:83-90, https://doi.org/10.4102/abc.v28i1.623. 